\title{
HOW TO DECIDE WHEN TO ADAPT COASTAL PROTECTION TO CLIMATE CHANGE
}

\author{
Per Soerensen $^{1}$, John Jensen ${ }^{2}$ and Peter Klagenberg ${ }^{3}$
}

This paper presents 2 objectives ways to decide when and how to adapt coastal protection to climate change. These two are risk analysis based on the EU-Flooding directive and the other is a socioeconomically analysis based on the Danish Ministry of Transports manual.

Keywords: climate change; decision support, coastal protection; Risk analysis; socioeconomic analysis

\section{Introduction}

Traditionally most of the coastal protection has been designed to resist an impact of a certain magnitude, normally represented by a certain return period incidence. This approach only takes into account the probability of failure of the coastal protection, reflecting the probability of flooding of the hinterland or erosion of the shore. It does not take into account the value that will be damaged by the flooding or eroded away respectively. The same approach is often used in spatial planning e.g. when the levels of foundation of houses are decided.

With a future accelerated sea level rise and increasing storminess there is a need for developing decision support systems that include decision criteria, so coastal protection can be designed taking into account both the probability of failure of flooding and the values that will be damaged by that. Furthermore, the decision support system must be able to tell when the right time is to include the effect of climate change in the coastal protection or coastal spatial planning.

This is especially important in Denmark with its $7300 \mathrm{~km}$ coastline of which most are privately owned and a lot have coastal protection. Each landowner must by him selves decide when and how to adapt the coastal protection to climate change. Many think it is now heavily influenced by the media attention towards Al Gores and others and the hype towards Denmark hosting the COP15 in 2009. On top of that the Inner Danish coasts were hit by to rare storm in 2006 and 2007. So it is important to have a system that can provide sufficient support to make an objective decision when to adapt to climate change.

Furthermore the spatial planning in Denmark is mainly done by decision makers that are elected for a 4 year period. If they must make decisions that are socioeconomically profitable on a long term but not in a short term (4 years), which could be deciding not to allow building of houses in an area that will be flood pruned in 2030, they must given decision support system that supports the decision.

The Danish Coastal Authority has developed two such a decision support systems. One based on risk analysis and the other based on socioeconomic analysis and includes the risk analysis (Jensen, Jørgensen and Klagenberg, 2009). For both dike and dune flood protected areas risk assessments and socioeconomically analysis have been carried out. The methods are also applicable for erosion protected areas. One example is the town of Løgstør placed by the Limfiord in a low lying flood prone area. The town has been flooded on several occasions and a low concrete wall now has been constructed to prevent the town from being flooded.

\section{Risk analysis - short intruduction}

A risk analysis is a systematic, understandable and formal procedure to quantify the probability and intensity of a certain hazard and the subsequent possible consequences in a specific area in case of failure. Within this definition, the risk analysis is composed of two sub-analyses: the hazard analysis and the vulnerability analysis (see Figures 2-1 and 2-4). In the hazard analysis the effect of climate change is included. Risk assessment is a sub-process of the risk analysis in which the results of the hazard analysis and the vulnerability analysis are tied together. The result of the risk assessment is the predicted risk for a specific area. The calculated risk value corresponds to an annual expectation value of damage and is expressed as a monetary value pr. year (Piontkowitz T., Sørensen C., 2004).

The Risk analysis in this paper is made according to the EU-Flooding directive (Directive 2007/60/EC).

\footnotetext{
${ }^{1}$ Head of coastal research, Danish Coastal Authority, Højbovej 1, 7620, Lemvig, Denmark, pso@kyst.dk

2 Senior coastal engineer, Danish Coastal Authority, Højbovej 1, 7620, Lemvig, Denmark, ii@kyst.dk

${ }^{3}$ Coastal morphologist, Danish Coastal Authority, Højbovej 1, 7620, Lemvig, Denmark, pak@kyst.dk
} 


\section{Socioeconomically analysis - short introduction}

A Socioeconomically analysis is a systematic, understandable and formal procedure to quantify economical benefits of a given coastal protection scheme. By doing so it is possible to calculate the socioeconomic value and compare it to other schemes.

The analysis in this paper is made according to the Danish Ministry of Transport manual ( ) which has a calculation period of 50 years. In the analysis consists of comparison of the economical costs and benefits for each year for two scenarios. The first scenario is a basis scenario of continuation of the present coastal protection. The second scenario is the project scenario where it assumed that a given coastal protection scheme is done at a certain time.

The result of a socioeconomically analysis is 3 values: Net profit, internal rate and net benefit pr. public invested monetary unit. The net profit is the calculated net benefit by the investment in the coastal protection and is expressed as a monetary value. The internal rate indicates the yearly return of the investment and is expressed as a percentage, and should be at least the states calculation rate, which is $6 \%$. The net benefit pr. public invested monetary unit is the relation between the net benefit and the net costs both expressed as net values.

\section{Løgstør case}

\section{Hazard analysis, Løgstør case}

The hazard analysis will be described by using a specific location Løgstør, which is situated in a fiord in Denmark. The fiord connects the North Sea in west to Kattegat in east, see Fig. 1.

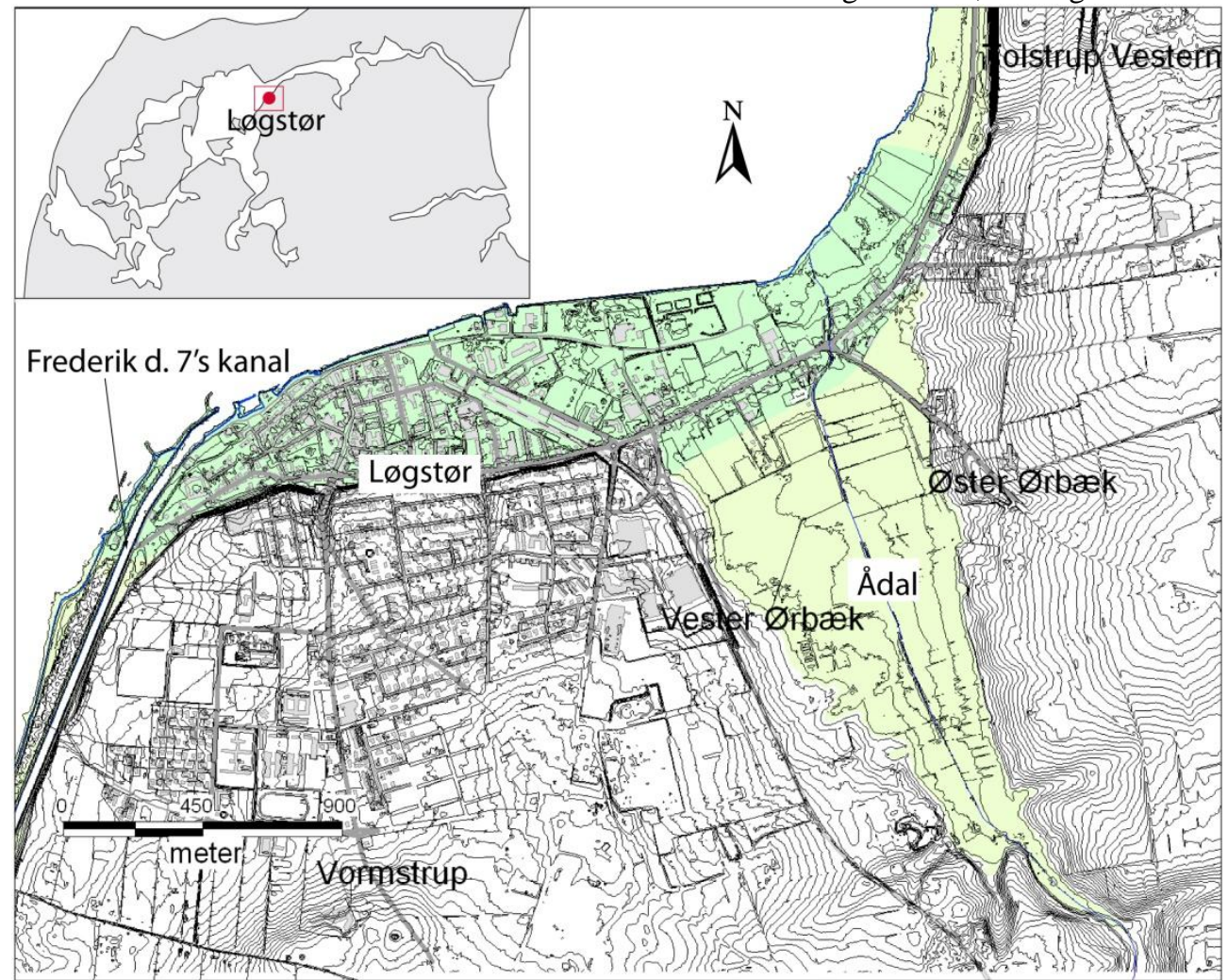

Figure 1. The location of the city of Løgstør. The low laying flood proned area below $4.5 \mathrm{~m}$ above sea level is shown in green.

The storm water level in Løgstør consists of 3 parts: The storm water level described by storm water level statistics, the future relative mean sea level rise caused by climate change including isostatic movement of the land and the future change in wind setup as a result of climate change.

The storm level statistics are calculated from water level recordings in Løgstør harbour from the period from 1930-2006. Log-Normal distribution describes the distribution of the extreme waterlevels best and results in a 50 year return period of $181 \mathrm{~cm}$ and the 100 year return period is $194 \mathrm{~cm}$ with a standard deviation of $15 \mathrm{~cm}$. The storm level statistic represent statistically the return periods up til a 200 years return period. In the hazard analysis it is necessary to describe up till 1.000.000 year return period, hence the statistic is logarithmic extrapolated. 
The future climate is only described by one climate change scenario, A2, because this shows how to do. In reality more than one climate change scenario must be used, both because the future climate is uncertain and to test the sensitivity to climate change. The A2 scenario is chosen because is the only scenario that are downscaled to a local Danish model. The isostatic movement has been projected into the future assuming that the land movement will continue with the same rate as in the past.

In the STOWASUS projected it was reported that the increase in the storm water level due to wind setup is expected to be $10 \%$ until the period 2060-89. Based on that an increase at $5 \%$ is expected in Løgstør due to less fetch. The wind setup becomes larger when the return period increases. The resulting storm water level statistics can be seen in Fig. 2.

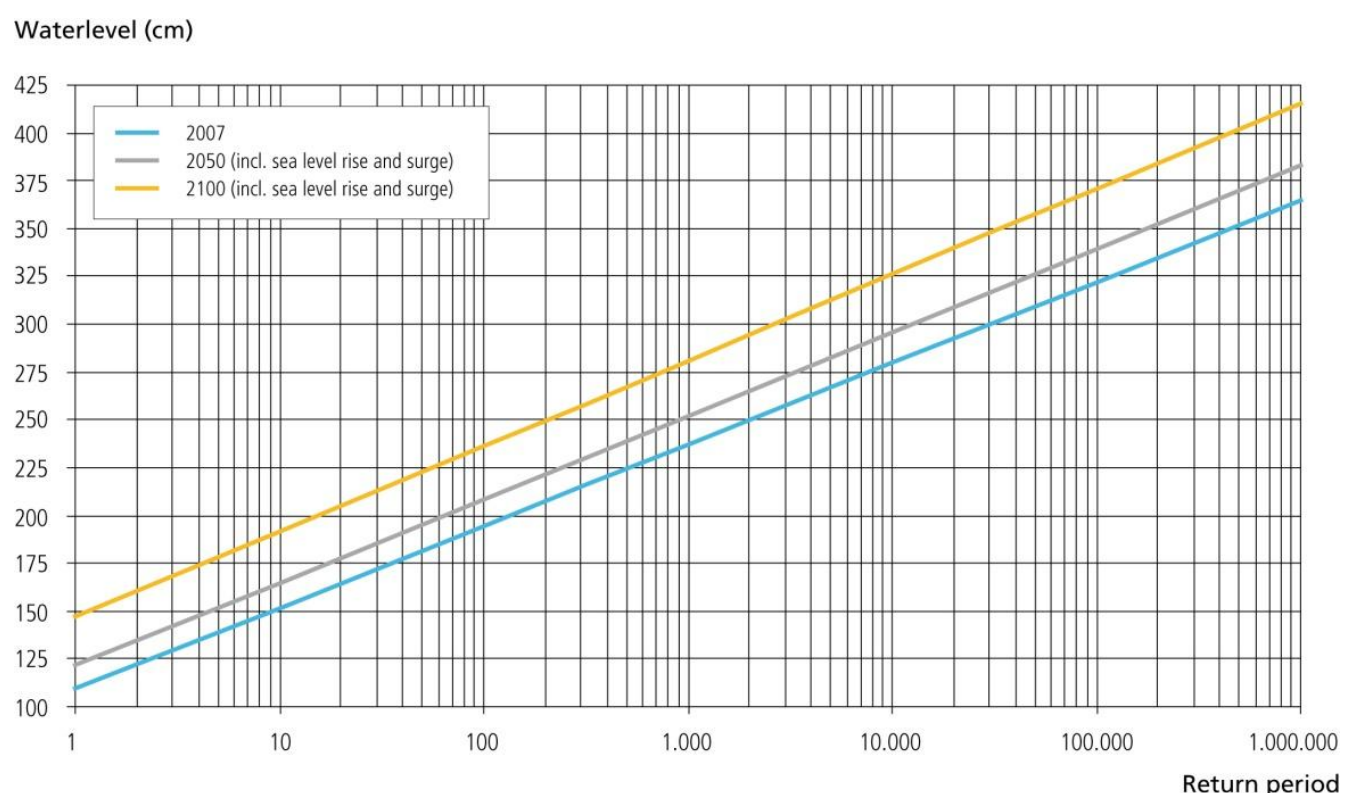

Figure 2. Storm water level statistics for Løgstør based on IPCC A2 scenario and including isostatic land movement and local wind seup.

In a hazard analysis the probability of flooding must be calculated for a representative range of return periods for each year. In this case it must represent the range from 1 to 1.000 .000 years. Let us assume we use the 10.000 year return period in 2100 which is $325 \mathrm{~cm}$. During such a storm $325 \mathrm{~cm}$ represents the maximum water level, so in order to reproduce that 10.000 year storm in a realistic way the progression of the storm water level must be described. This has been done by analyzing the time series from 5 storms that resulted in the highest water levels. The time series were normalized using the maximum water level and an average "standard" storm were calculated as can be seen in Fig. 3. 


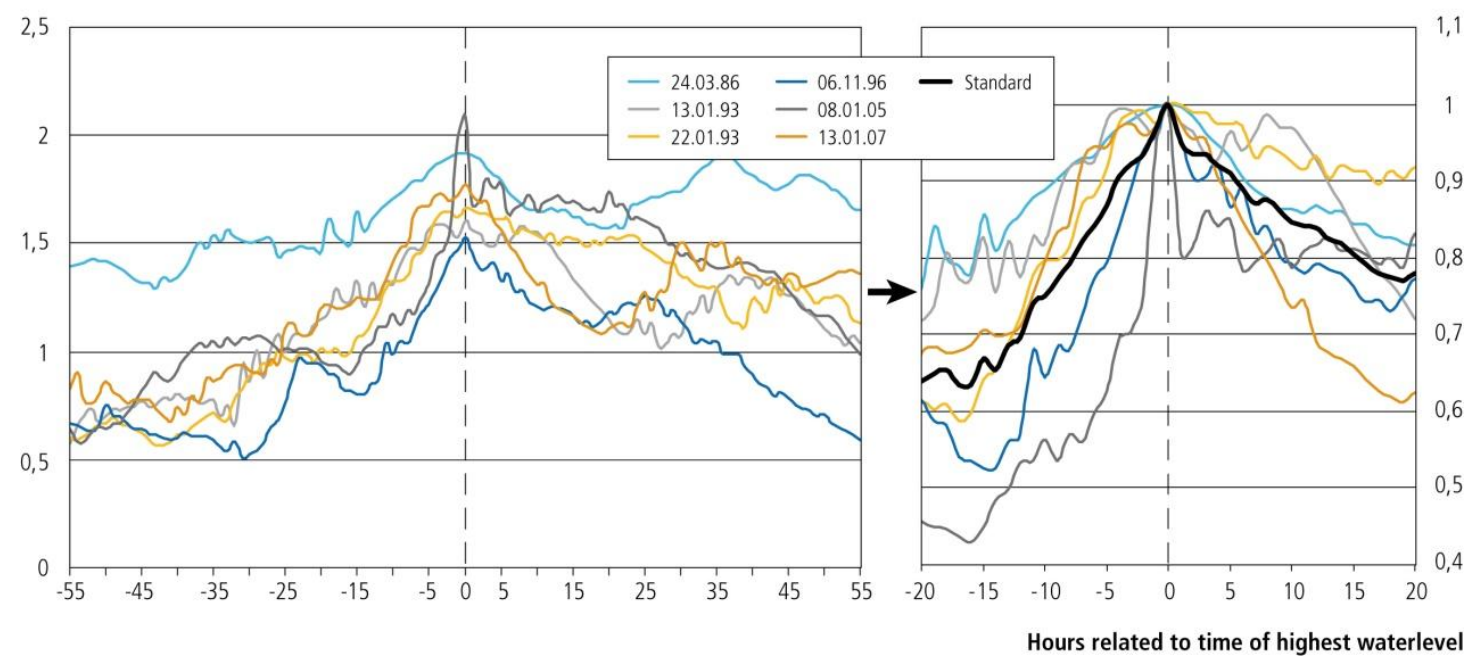

Figure 3. Calculation of the standard progress of a storm in Løgstør based on the $\mathbf{5}$ highest storms.

Now we have the probability of occurrence of certain water levels now and in the future including the effect of climate change. To each maximum water level a corresponding time series for the progression of that storm has been calculated. The next step in the hazard analysis is the calculation of which areas that are flooded and the corresponding inundation level.

This is done by using the numerical model Mike Flood which is a dynamical 2-d flooding model that simulates flooding in a dynamical ways. It is also possible to take time dependent breaching processes into account. The input to Mike Flood is the bathymetry shown in Fig. 1. And a storm surge time series based on the standard storm shown in Fig. 2. And the present and future storm water level statistics show in Fig. 2. In the topography the present flood protection wall is detailed described, and all buildings are raised to realistic height which makes it possible to simulated that the real waterways in a city is via roads. The model has been calibrated using the recorded flooding inundation depth from a storm that hit Løgstør the $8^{\text {th }}$ of January 2005 which was a 180 year event.

The model has been run on numerous combinations of return periods and the years until 2100 . The progression of such a flood is shown in Fig. 4. Because the flood protection is a vertical concrete wall it is assumed that the wall won't get damage so the flooding will happen as a pure overflow of the wall or/and a flow around the ends of the wall. 

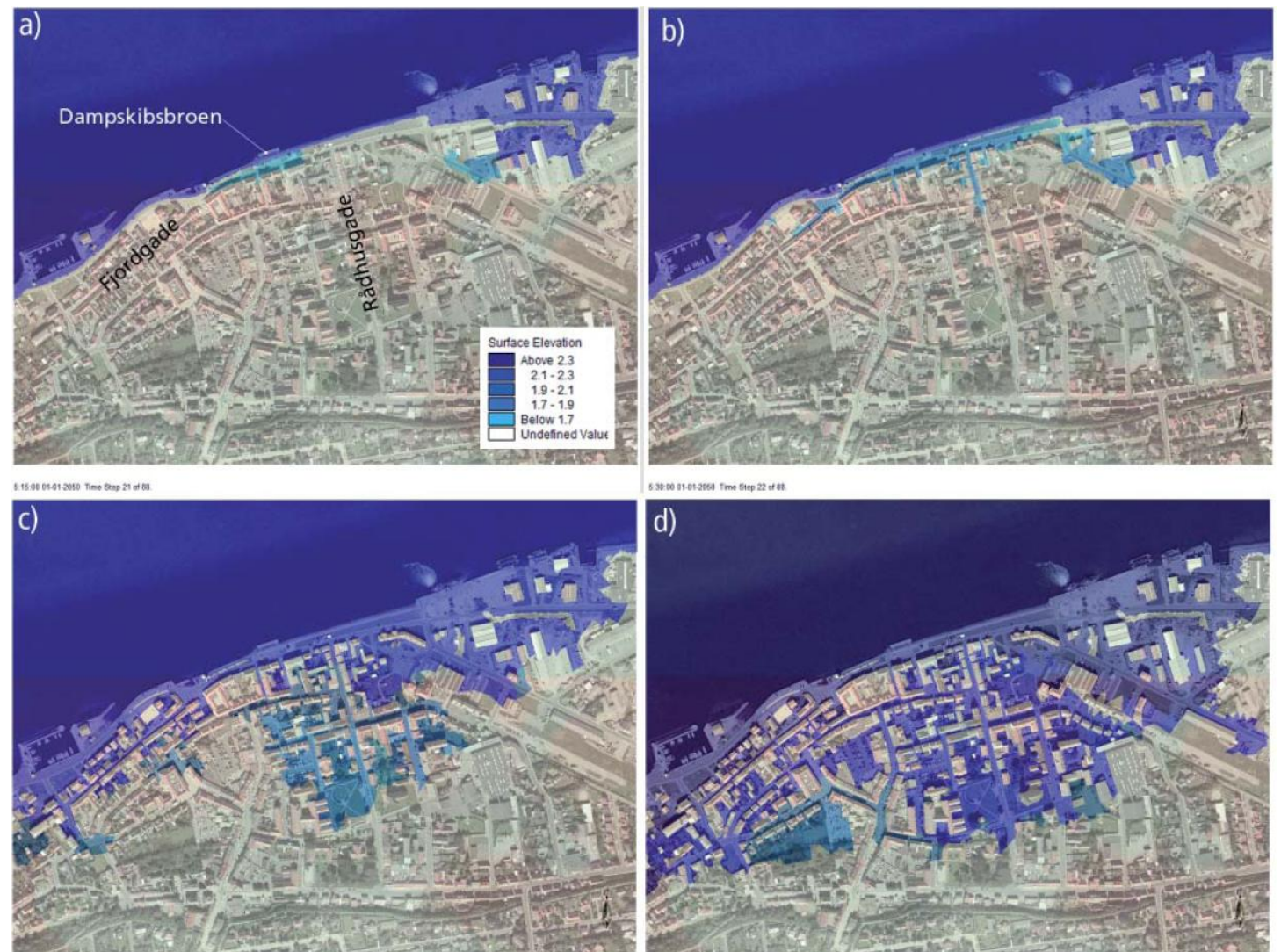

Figure 4. Four time steps of flooding. a) outer water level 2,21m, b) 15 minutes later, outer water level 2,24 m, c) 45 minutes later, outer water level 2,28 $\mathrm{m}$ og d) 60 minutes later, outer water level 2,32 $\mathrm{m}$

There has also been done many simulated with a raised and lengthened flood protection wall "constructed" in year 2050. For each simulation the maximum inundation depths are calculated, see an example in Fig. 5.

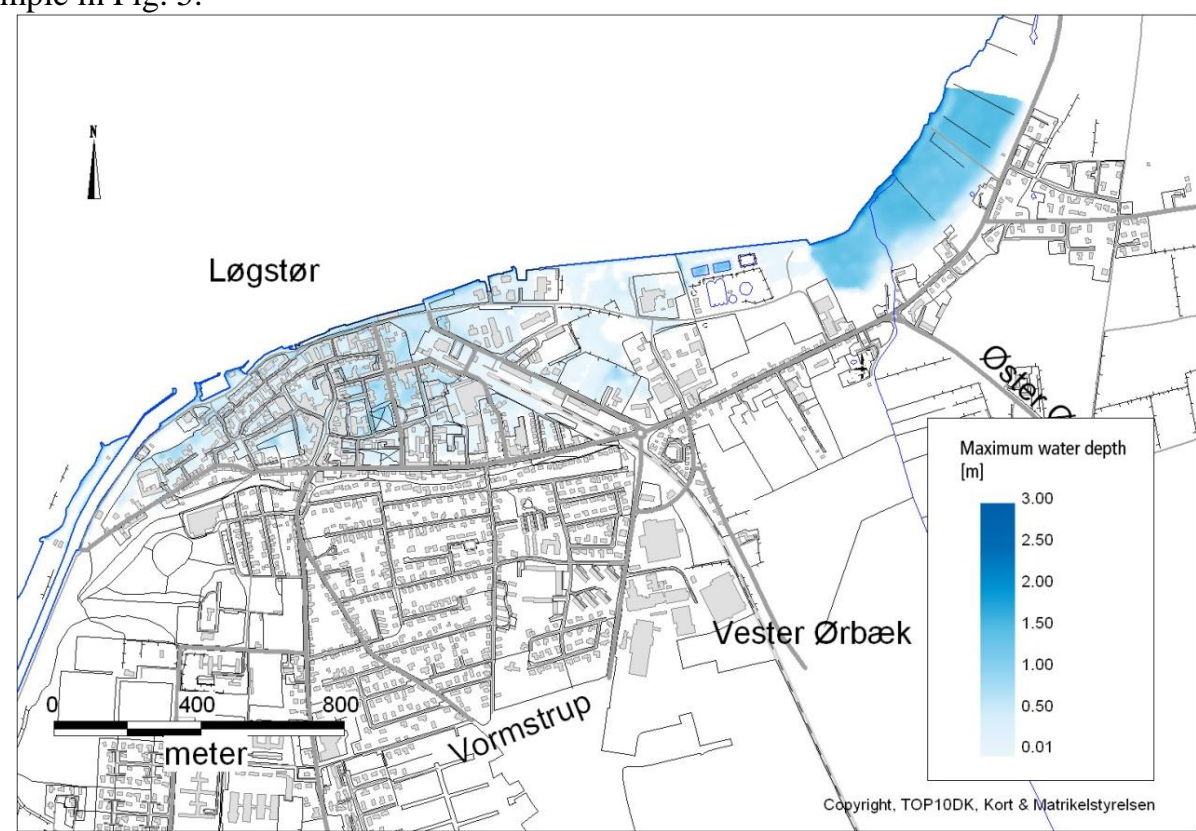

Figure 5. Maximum inundation depth for a 100 year MT storm with existing flood protection

So now we have calculated the probability of flooding at any location in Løgstør and the corresponding inundation depth until 2100 including climate change. 
Vulnerability analysis, Løgstør case

The vulnerability to flooding is traditionally divided into direct and indirect damages which again are divided into tangible and non-tangible damages (Reese S. 2003). In this work the focus will be on the tangible damages because of the scope of the decision support tools. The input to the tool must be quite easy to obtain. The result will give a good result. Further detailed description of the vulnerability will of course give a better and more detailed result, but will also cause a lot more effort to achieve, so how detailed the vulnerability is described must be dependent of the complexity and the values at stake.

In this analysis the basic data can be obtained quite easily through public registers and they are already geo referenced and therefore easy to use. The basic data consists of property values, building values, use of buildings, farming areas and roads outside the cities. For some of the data the values damaged will be depended of the inundation depth. The damage types, the corresponding basic data and the depth dependencies are shown in Table 1.

\begin{tabular}{|l|l|l|}
\hline \multicolumn{2}{|l|}{ Table 1. Type of damages, the corresponding basic data and the depth dependencies } \\
\hline Type of damage & Basic data & \\
\hline Damage on buildings & Building value & Depth dependent \\
Damage on furniture & Building value & Depth dependent \\
Damage on machinery and transport & Building value & Depth dependent \\
Damage on household & Building value & Depth dependent \\
Damage on crops, fertilizer and fodder & Building value & Depth dependent \\
Damage on infrastructure & Depending of several data & Not depth dependent \\
Operation loss agriculture & Area & Not depth dependent \\
Operation loss buildings & Building value & Not depth dependent \\
Production loss & Type of use & Dot depth dependent \\
Damage on coastal protection & & Depth dependent \\
\hline
\end{tabular}

For the depth dependent damages only the building values is known, so the values of the other damage types most be known. From a previous study from a benefit/cost analysis of the Danish Wadden sea dike the damage potential in percentage of the building values is used (Udvalget 1973), see Table 2.

\begin{tabular}{|c|c|c|c|c|c|c|}
\hline \multirow[t]{2}{*}{ Damage type } & \multicolumn{6}{|c|}{ Type and use of buildings } \\
\hline & Houses & Farms & Cottages & Industry & $\begin{array}{l}\text { Public } \\
\text { Institution }\end{array}$ & Supply \\
\hline $\begin{array}{l}\text { Buildings } \\
\text { Furniture }\end{array}$ & $\begin{array}{r}100 \% \\
50 \%\end{array}$ & $100 \%$ & $\begin{array}{r}100 \% \\
20 \%\end{array}$ & $\begin{array}{r}100 \% \\
50 \%\end{array}$ & $100 \%$ & $\begin{array}{r}100 \% \\
20 \%\end{array}$ \\
\hline $\begin{array}{l}\text { Machinery and transportation } \\
\text { Livestock }\end{array}$ & $10 \%$ & $\begin{array}{l}40 \% \\
30 \%\end{array}$ & $1.5 \%$ & $10 \%$ & $0 \%$ & $10 \%$ \\
\hline Crops, food and fertilizer & - & $10 \%$ & - & - & - & - \\
\hline
\end{tabular}

Now the damage potential as a percentage of the building value has been calculated, and now the damage percentage of that value dependent of the inundation depth has to be decided. These percentages has also been taken from (Udvalget 1973), see Table 3.

\begin{tabular}{|l|r|r|r|}
\hline Table 3. Damage dependence of the inundation depth \\
\hline Type of damage & \multicolumn{3}{|c|}{ Water dept [m] } \\
\cline { 2 - 4 } & $\mathbf{0 . 5}$ & $\mathbf{1 . 5}$ & $\mathbf{4 . 5}$ \\
\hline Buildings & $30 \%$ & $43 \%$ & $83 \%$ \\
Furniture & $70 \%$ & $74 \%$ & $88 \%$ \\
Machinery and transportation & $20 \%$ & $80 \%$ & $80 \%$ \\
Livestock & $50 \%$ & $100 \%$ & $100 \%$ \\
Crops, food and fertilizer & $50 \%$ & $100 \%$ & $100 \%$ \\
\hline
\end{tabular}

As can be seen there is a strong dependence between inundation depth and damage. Especially for the livestock the consequence of large water depth can be seen.

For the not depth dependent damages is all the data in this analysis standardized. The damages in this case are damage on infrastructure or operation losses. Damage on infrastructure is damage on pipes, electrical installation, roads, railways etc. and varies a lot from place to place. Conservative the damage is estimated to $2.5 \%$ of the construction costs. 
If farmland is flooded not only is the crops damaged but also the soil it selves which means that if new seeds are sown the outcome is expected to be less than before the area was flooded. Flooding of a farm will cause immediate losses but also operation losses from the time the farm is flooded until operations are normalized. Both values have been estimated by a farming consultant (Kystdirektoratet 2006).

If houses are flooded then there will be some extra costs caused by the necessarily to move people to another house while the flooded house are renovated. These costs are also estimated and varies according to the use of the house (Normal house, farm house and holiday house).

If companies are flooded there will also be operation losses until the former activities are reestablished. These losses are estimated by using the number of employees, number of lost working hours and the salary pr hour.

There are many non-tangible damages that are difficult to valuate because the value can be very subjective, but they can have a great influence on where people decide to live or place their company hence it is important to a least consider these. Examples of these are reduced confidence in how safe it is to live in the flood proned area. Another example is the loss of cultural heritage.

\section{Risk analysis, Løgstør case}

Based on the results obtained in the previous vulnerability and hazard analysis the risk can be calculated. The risk is calculated for each of the addresses, and summed up in squares of $100 * 100 \mathrm{~m}$ to make an overview of the risk. The risks are given in Danish kroner Dkr. An example of the calculated risk in 2008 and 2050 with the present flood protection can be seen in Fig. 6 and Fig. 7 respectively. The hazard analysis is the same in the two examples, so the changes in risk are only an effect of climate change.

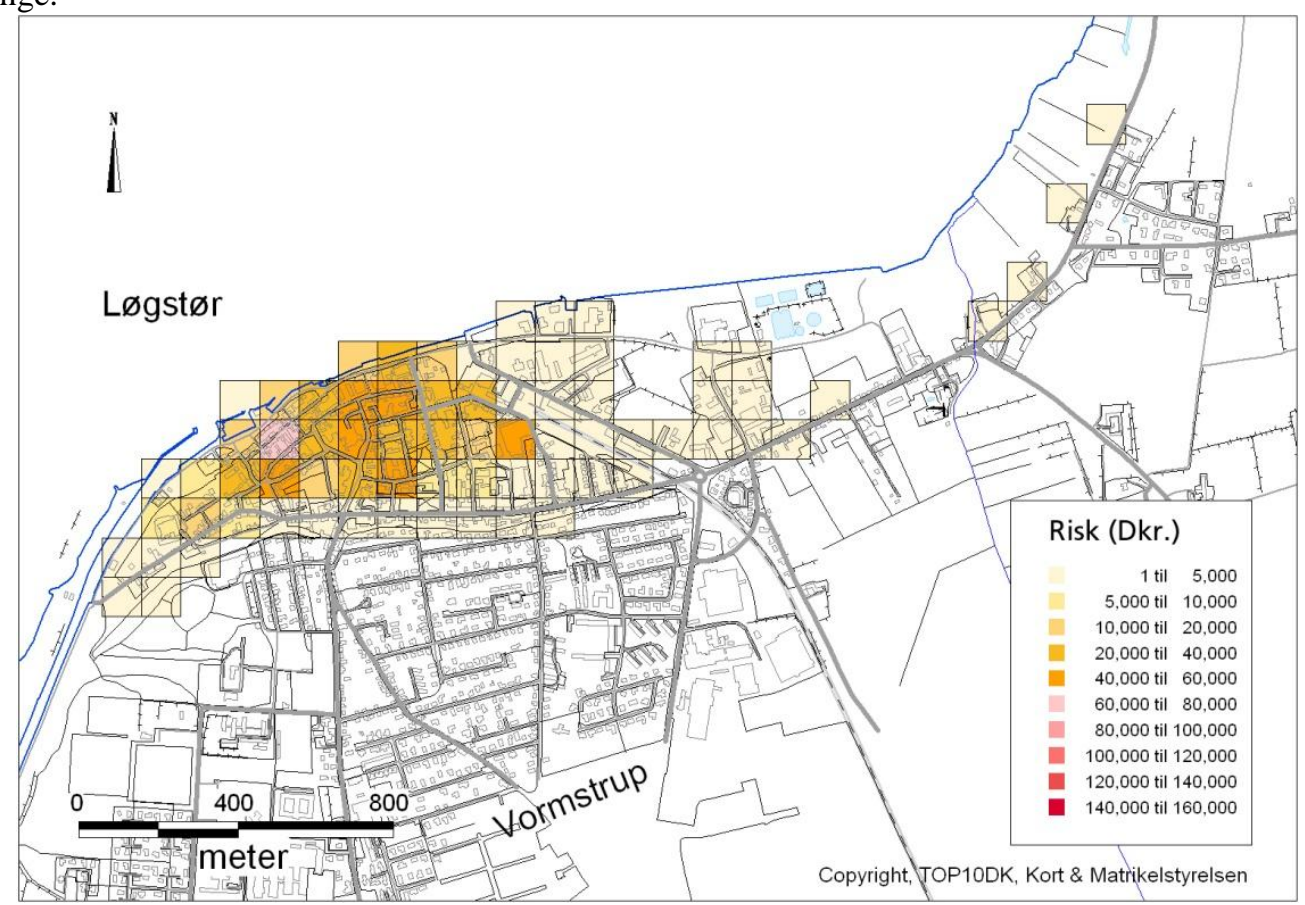

Figure 6. Calculated risk. 2008 situation with existing flood protection 


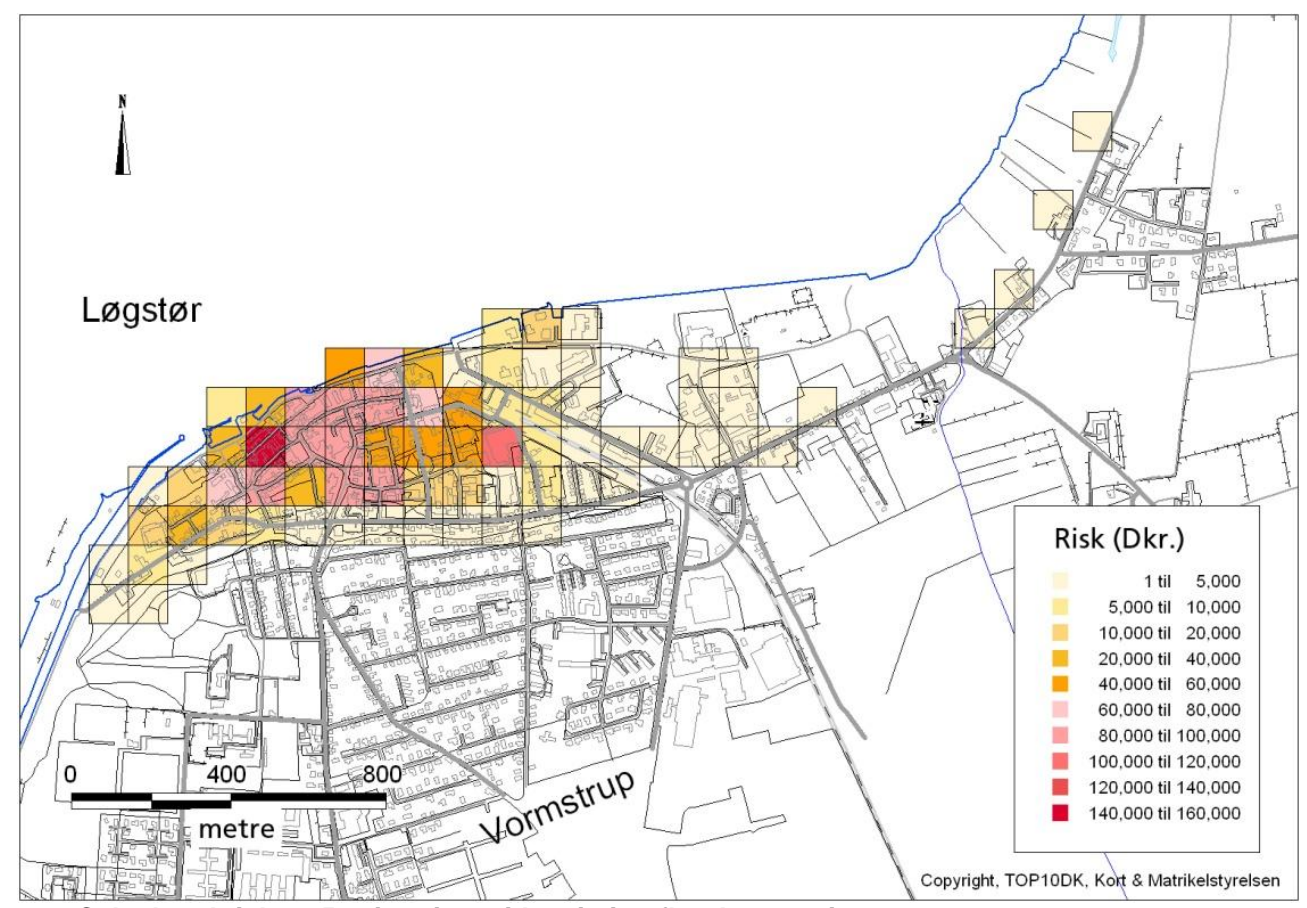

Figure 7. Calculated risk. 2050 situation with existing flood protection

The risk maps in Fig. 6 and 7 can be used in combination with the risk analysis to decide when the impact from sea level rise increases the risk above an acceptable value. Let us assume that the municipality has decided that the maximal acceptable risk is 40.000 to $60.000 \mathrm{Dkr}$., then it can be seen that in 2008 there is no problem, but in 2050 there is. Something must be done. But what should be done and when?

There are two possibilities, either reduce the hazard or reduce the vulnerability. Reducing the hazard can be done by reducing the climate change, maybe the preferable option but certainly not one that can be done locally! It can also be done by strengthening of the coastal protection. Reducing the vulnerability can be done by identifying where the main contributors to the vulnerability are. Looking at Fig. 6 they seem to be spread over large part of the city so there seems not to be an easy way to reduce the vulnerability. By analyzing the numerical flood modeling it can be identified that the existing flood protection wall seem to low in the future climate and extent to little towards east. Therefore an rise and extension of the flood protection wall is analyzed. The proposed scheme can be seen in Fig. 8.

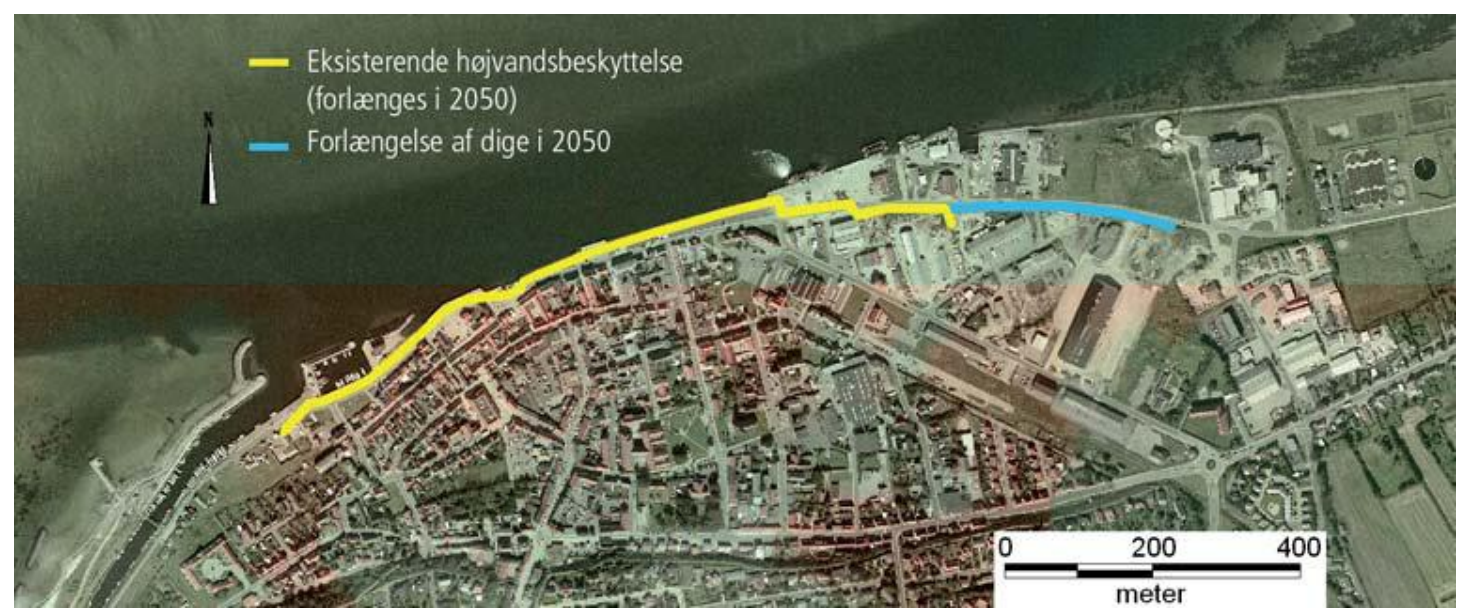

Figure 8. Strengthening of flood protection by raising the sea wall $0.4 \mathrm{~m}$ and extending it towards east 


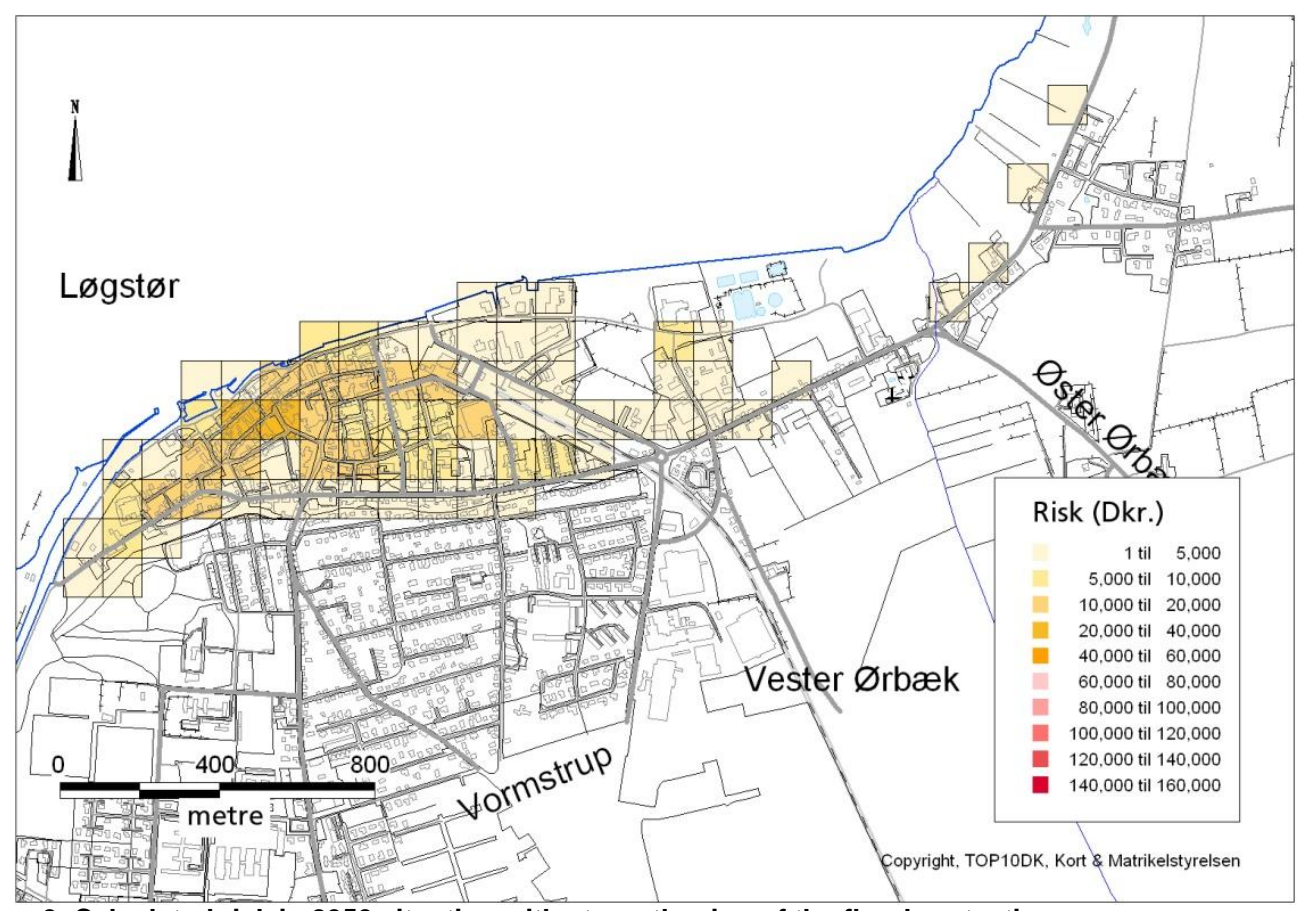

Figure 9. Calculated risk in $\mathbf{2 0 5 0}$ situation with strengthening of the flood protection

A clear reduction down to acceptable risks can be seen with the strengthened flood protection. So the above described risk analysis is an example of how risk analysis can be used as an objective decision support tool to decide how and when to adapt to climate change.

Reducing the risk can be one parameter but what if the economy is important to the decision makers? How can they decide whether it a good idea to reduce the risk in a more holistic sense that just addressing the risk parameter?

\section{Socio economical analysis, Løgstør case}

As described in the beginning of this paper socio economical analysis is an objective way to quantify societies benefit of a given coastal protection scheme. In the analysis the basic scenario is the present flood protection and the project scenario is heightening of the concrete wall by $0.4 \mathrm{~m}$ in 2050 and at the same time extends it $420 \mathrm{~m}$ towards east. It that a clever decision in a socioeconomically sense? To calculate that principally for each year from the start and to year 2100 in this case the expected damages and the expected costs to coastal protection are calculated. The saved costs (benefits) can be summed up and compared to the summed costs to calculate the net profit and other economical parameters. In Table 4 the calculations are shown in summarized form.

Table 4. Socioeconomically calculations for increasing height of and extending sea wall, Løgstør.

\begin{tabular}{|c|c|c|c|c|c|c|c|c|c|}
\hline \multirow[t]{2}{*}{ Scenario } & \multirow[t]{2}{*}{ Category } & PV & \multicolumn{7}{|c|}{ Yearly expenses } \\
\hline & & $\begin{array}{l}\text { Mio. } \\
\text { Dkr. }\end{array}$ & 2050 & 2051-59 & $2060-69$ & $2070-79$ & $2080-89$ & $2090-98$ & 2099 \\
\hline \multirow[t]{2}{*}{ Basic } & $\begin{array}{l}\text { Expected } \\
\text { damages }\end{array}$ & 42.6 & 1.96 & 1.96 & 2.53 & 3.31 & 4.46 & 6.16 & 6.16 \\
\hline & $\begin{array}{l}\text { Costs coastal } \\
\text { Protection }\end{array}$ & 8.0 & 0.51 & 0.51 & 0.51 & 0.51 & 0.51 & 0.51 & 0.51 \\
\hline \multirow[t]{6}{*}{ Project } & $\begin{array}{l}\text { Expected } \\
\text { damages }\end{array}$ & 10.3 & 1.96 & 0.40 & 0.52 & 0.69 & 0.94 & 1.31 & 1.31 \\
\hline & $\begin{array}{l}\text { Costs coastal } \\
\text { protection }\end{array}$ & 10.0 & 2.14 & 0.54 & 0.54 & 0.54 & 0.54 & 0.54 & 0.07 \\
\hline & $\begin{array}{l}\text { Saved } \\
\text { damages }\end{array}$ & 32.3 & 0.00 & 1.56 & 2.01 & 2.62 & 3.52 & 4.85 & 4.85 \\
\hline & Costs & -2.0 & -1.64 & -0.03 & -0.03 & -0.03 & -0.03 & -0.03 & 0.44 \\
\hline & Tax distortions & -0.3 & -0.28 & -0.01 & -0.01 & -0.01 & -0.01 & -0.01 & 0.07 \\
\hline & $\begin{array}{l}\text { Net } \\
\text { benefit(NPV) }\end{array}$ & 29.9 & -1.92 & 1.53 & 1.97 & 2.59 & 3.48 & 4.81 & 5.36 \\
\hline
\end{tabular}


PV is the present value which is the investments and saved damages capitalized to the base year. To do this the Danish states official calculation rate of $6 \%$ has been used. The net benefit of the investment in heightening and extension of the flood protection wall is summed up in the Net Present Value (NPV) which is the difference between the present value (PV) of saved damages and costs including the tax distortions.

There are two other economical parameters that qualify the profitability of the project. It is the Net Benefit pr. Public Investment (NBPI) which should be greater than 0 and the internal rate, which is the yearly socioeconomically, return of the investment. It is calculated as percentage and should be larger than $6 \%$.

In this case the NBPI is $13 \mathrm{kr}$. And the internal rate is $80 \%$. So both parameters also supports that the proposed heightening and extension of the sea wall in 2050 in a good investment.

The economical calculations are based on assumptions of damage percentages, loss due to inundation depth and other assumptions. On such a basis do the economical parameters represent a realistic picture of the real damages? To answer that a sensitivity analysis has been done. The most significant costs damage on buildings and on furniture has been reduced by $50 \%$ and $35 \%$ respectively. The associating NBPI is still well above 0,26 and $28 \mathrm{kr}$. and the internal rate is 65 and $70 \%$.

To find the best combination of solution and the time to implement it a number of different combinations can easily be tested because the model setup is the same. Fig. 10 Shows an synthetic example of that given a raise of 0.5 and $1 \mathrm{~m}$ in 5 different years and the resulting net value NPV.

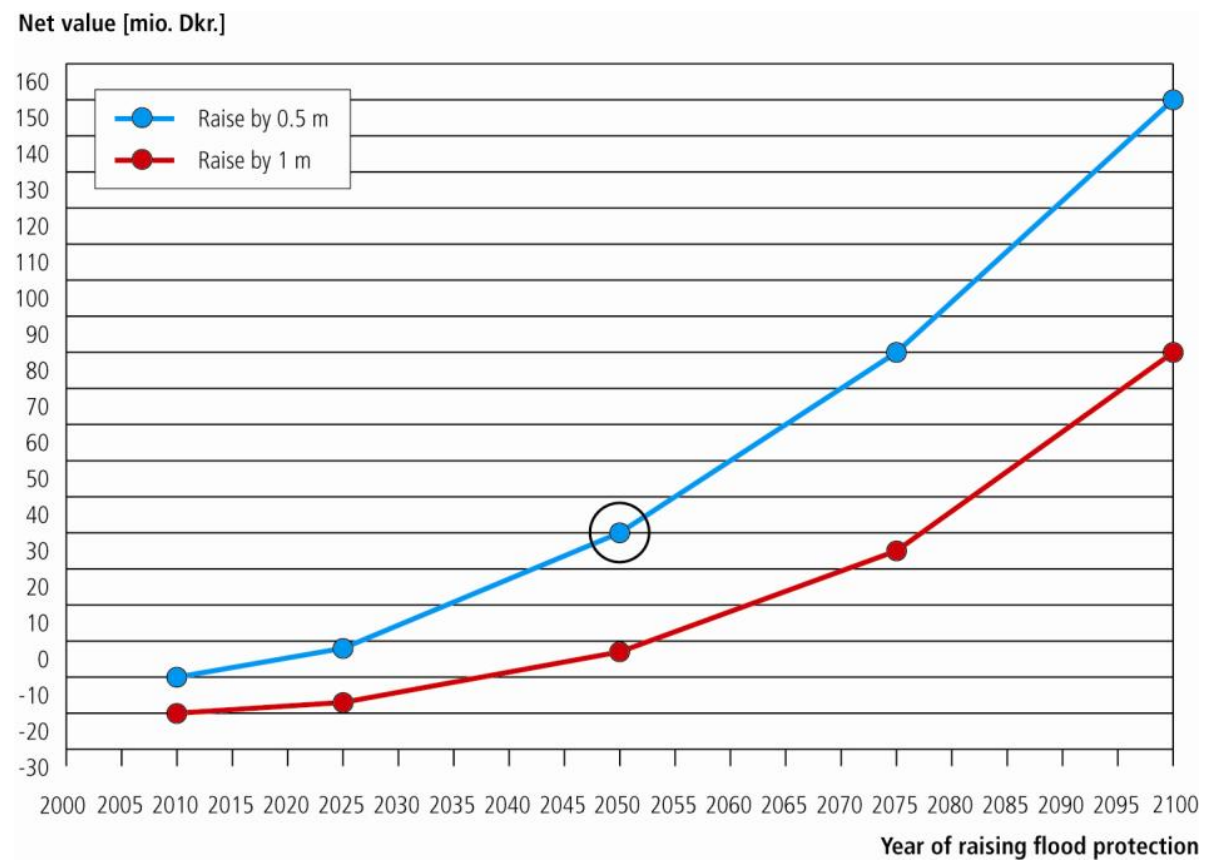

Figure 10. Synthetic example of two flood protection schemes and time of implementation.

\section{Dalby bay case}

Similar risk and socioeconomically analysis has been carried out for Dalby bay on the northern part of the Danish island Funen. The summer cottages in the bay were flooded once each year in 2006, 2007 and 2008. In 2008 it was decided that the risk was to high and a dike was build protecting from flooding from the bay and from a creek, see Fig. 11. 


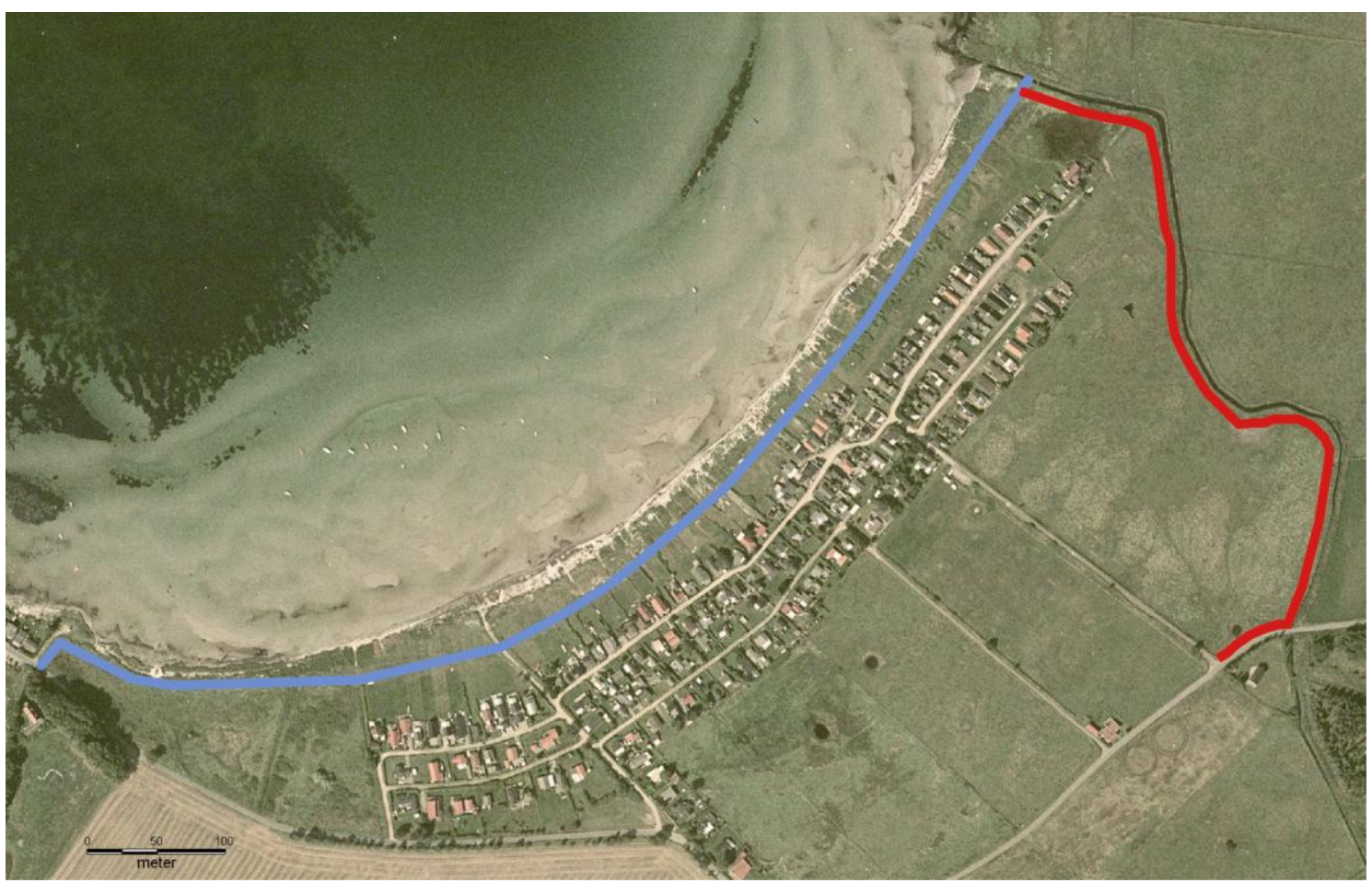

Figure 11. Dalby bay and location of the dike build in 2008

\section{Risk analysis, Dalby bay case}

The calculated risk before and after construction of the dike can be seen in Fig. 12 and 13, respectively. A clear reduction of the risk can be seen as a result.

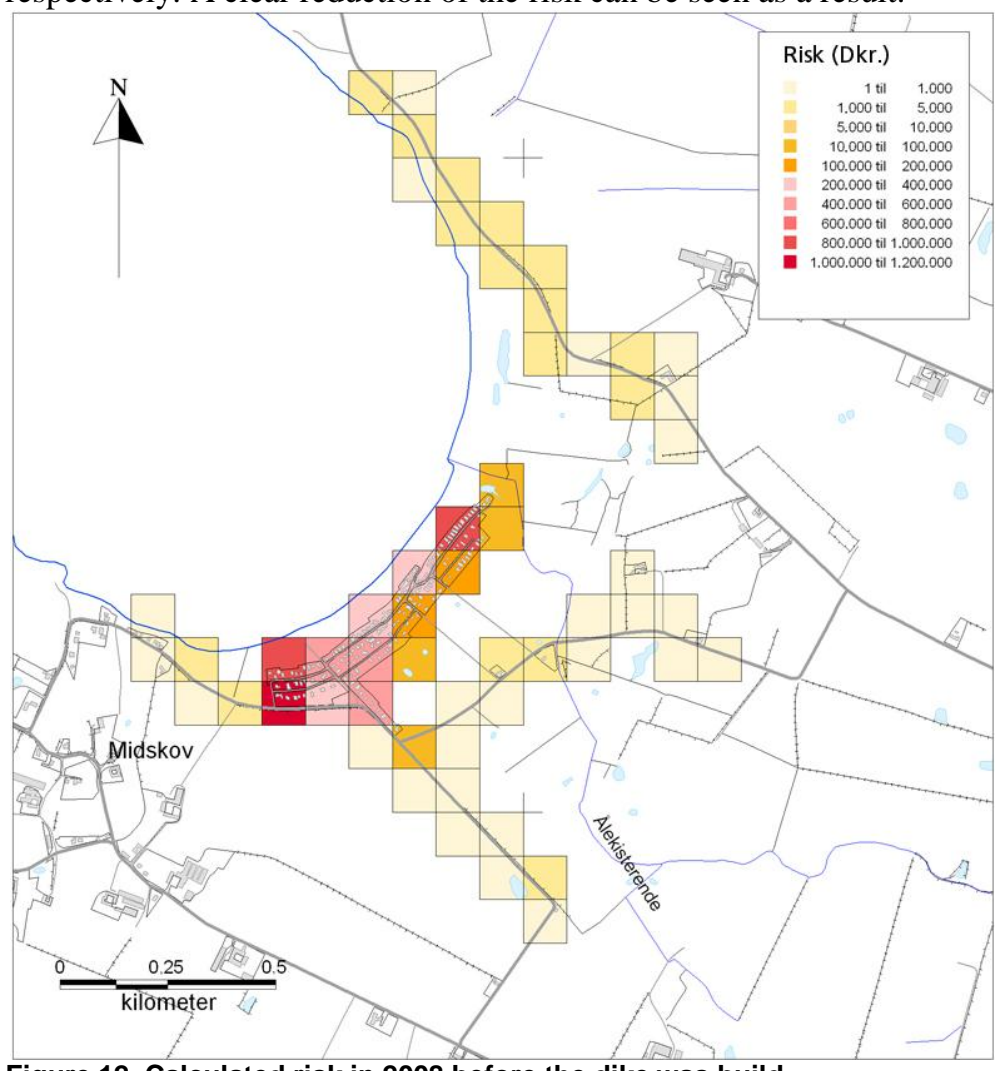

Figure 12. Calculated risk in 2008 before the dike was build 


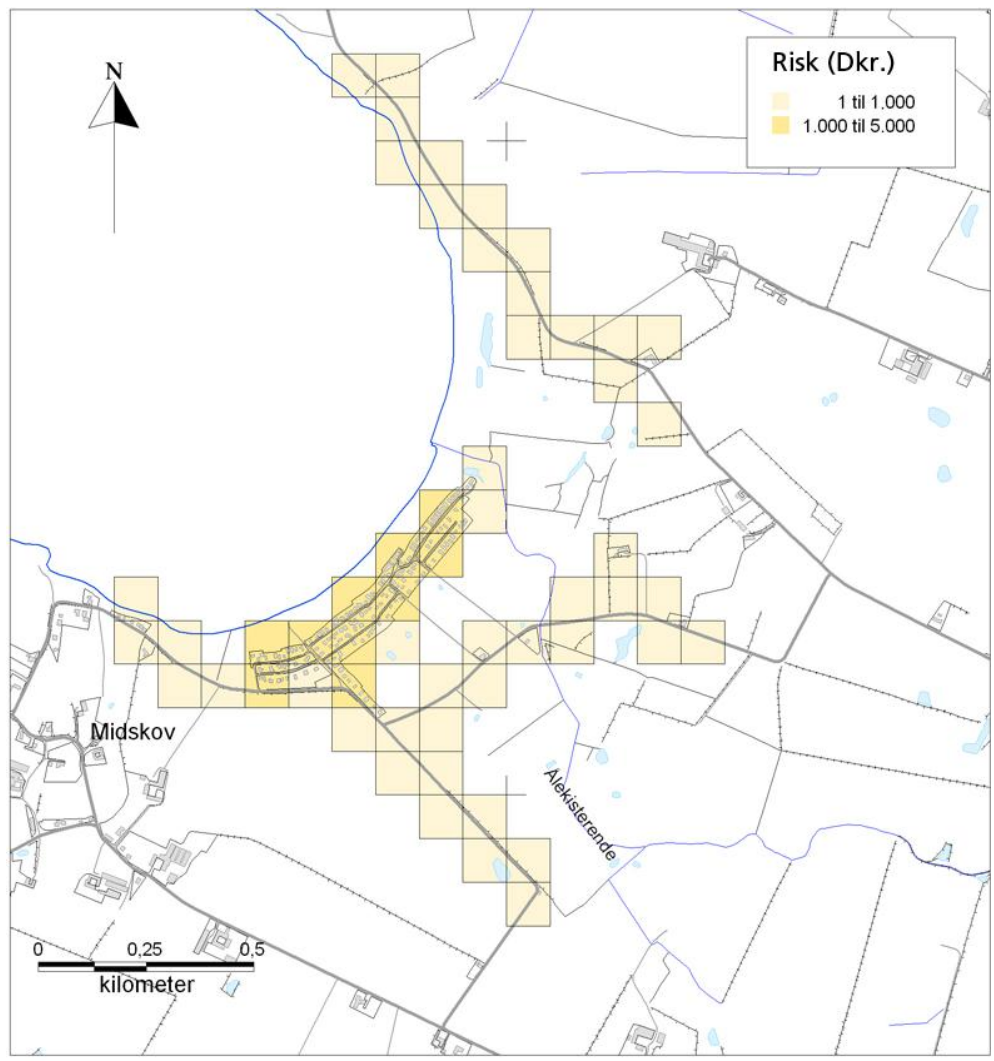

Figure 13. Calculated risk in 2008 after the dike was build

\section{Socio economical analysis, Dalby bay case}

Similar to the Løgstør case a socio economically analysis has been carried out. In this case the calculation period has been chosen to 50 years in order to include the effect of climate change and also taken into account that the lifetime of the holiday house are expected to be 50 years. In Table 5 the calculations are shown in summarized form.

\begin{tabular}{|c|c|c|c|c|c|c|c|c|c|}
\hline \multirow[t]{2}{*}{ Scenario } & \multirow[t]{2}{*}{ Category } & \multirow{2}{*}{$\begin{array}{c}\text { PV } \\
\text { Mio.kr }\end{array}$} & \multicolumn{7}{|c|}{ Yearly expenses } \\
\hline & & & 2008 & $2009-17$ & 2018-27 & $2028-37$ & $2038-47$ & $2048-56$ & 2057 \\
\hline \multirow[t]{2}{*}{ Basic } & Expected & 115.8 & 6.16 & 6.16 & 7.12 & 8.40 & 10.12 & 12.51 & 12.51 \\
\hline & $\begin{array}{l}\text { Costs coastal } \\
\text { Protection }\end{array}$ & 0 & 0 & 0 & 0 & 0 & 0 & 0 & 0 \\
\hline \multirow[t]{5}{*}{ Project } & $\begin{array}{l}\text { Expected } \\
\text { damages }\end{array}$ & 0.5 & 0 & 0.02 & 0.03 & 0.03 & 0.04 & 0.05 & 0.05 \\
\hline & $\begin{array}{l}\text { Costs coastal } \\
\text { protection }\end{array}$ & 2.4 & 2.06 & 0.04 & 0.04 & 0.04 & 0.04 & 0.04 & -2.02 \\
\hline & $\begin{array}{l}\text { Saved } \\
\text { damages }\end{array}$ & 103.8 & -6.16 & 6.14 & 7.09 & 8.36 & 10.07 & 12.45 & 12.45 \\
\hline & $\begin{array}{l}\text { Costs } \\
\text { Tax distortions }\end{array}$ & $\begin{array}{l}-2.4 \\
-0.4\end{array}$ & $\begin{array}{l}-2.06 \\
-0.35\end{array}$ & $\begin{array}{l}-0.04 \\
-0.01\end{array}$ & $\begin{array}{l}-0.04 \\
-0.01\end{array}$ & $\begin{array}{l}-0.04 \\
-0.01\end{array}$ & $\begin{array}{l}-0.04 \\
-0.01\end{array}$ & $\begin{array}{l}-0.04 \\
-0.01\end{array}$ & $\begin{array}{l}2.02 \\
0.34\end{array}$ \\
\hline & $\begin{array}{l}\text { Net } \\
\text { benefit(NPV) }\end{array}$ & 100.9 & -8.58 & 6.09 & 7.05 & 8.32 & 10.03 & 12.40 & 14.82 \\
\hline
\end{tabular}

In the Dalby case the NBPI is $35 \mathrm{kr}$. And the internal rate is $71 \%$. So both parameters also supports that the building of the dike is a good investment.

The sensitivity analysis shows also that the NBPI and internal rate is not sensitive to reduction of the significant damages on buildings 


\section{Summary}

Two decision support tools have been developed to assist decision makers adapting the coastal protection to climate change. One is based on risk analysis according to the European flooding directive and the other is based on socioeconomically analysis based on the Danish Ministry of Transports manual. Both can be used to decide when and how to adapt in an objective way. Once the tools have been set up it is straightforward to do additional "what if" analysis and also to include new findings (new climate change scenarios).

\section{REFERNCES}

Jensen J., Jørgensen J.B. and Klagenberg P. 2009. Manual for bestemmelser knyttet til den samfundsøkonomiske analyse samt oversvømmelsesdirektivet, Report, 34 pp.

Danish Government (2008). Danish strategy for adaptation to a changing climate, Publication, ISBN 978-87-7844-719-7, 48 pp

Danish Ministry of Transport (2003). Manual for samfundsøkonomisk analyse, Publication, ISBN 87 91013-36-4, $118 \mathrm{pp}$.

Piontkowitz T., Sørensen C. (2004). Risk assessment for the Wadden sea, Comrisk - Subproject SP 7 138 pp. plus appendices.

Reese S. (2003) Die Vulnerabilität des Schleswig-Holsteinischen Küstenraumes durch sturmfluten. Fallstudien von der Nord- und Ostseeküste. Ph. D. Thesis, Christian Albrechts Univertsity, Kiel

Udvalget (1973). Sekretariatet for udvalget vedrørende sikkerhedsforanstaltninger ved havdigerne I Tønder og Riube Amter (1973). Forstærkning af havdigerne i Tønder og Ribe Amter - Økonomisk vurdering. Report

Kystdirektoratet (2006) Kystdirektoratet-Risikoanalyse af en klitbeskyttet kyst. Report 